\title{
Interferon Lambda-2
}

National Cancer Institute

\section{Source}

National Cancer Institute. Interferon Lambda-2. NCI Thesaurus. Code C104349.

Interferon lambda-2 (200 aa, $\sim 22 \mathrm{kDa}$ ) is encoded by the human IFNL2 gene. This protein is involved in both cytokine-mediated signaling and antiviral activity. 